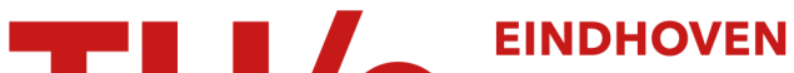 \\ UNIVERSITY OF \\ TECHNOLOGY
}

\section{Structural modelling, construction and test of the first 3d- printed gridshell in ice composite}

\section{Citation for published version (APA):}

Pronk, A. D. C., Li, Q., \& Mergny, E. (2020). Structural modelling, construction and test of the first 3d-printed gridshell in ice composite. Journal of the International Association for Shell and Spatial Structures, 61(3), 177186. https://doi.org/10.20898/j.iass.2020.001

DOI:

10.20898/j.iass.2020.001

Document status and date:

Published: 01/09/2020

\section{Document Version:}

Accepted manuscript including changes made at the peer-review stage

\section{Please check the document version of this publication:}

- A submitted manuscript is the version of the article upon submission and before peer-review. There can be important differences between the submitted version and the official published version of record. People interested in the research are advised to contact the author for the final version of the publication, or visit the $\mathrm{DOI}$ to the publisher's website.

- The final author version and the galley proof are versions of the publication after peer review.

- The final published version features the final layout of the paper including the volume, issue and page numbers.

Link to publication

\section{General rights}

Copyright and moral rights for the publications made accessible in the public portal are retained by the authors and/or other copyright owners and it is a condition of accessing publications that users recognise and abide by the legal requirements associated with these rights.

- Users may download and print one copy of any publication from the public portal for the purpose of private study or research.

- You may not further distribute the material or use it for any profit-making activity or commercial gain

- You may freely distribute the URL identifying the publication in the public portal.

If the publication is distributed under the terms of Article 25fa of the Dutch Copyright Act, indicated by the "Taverne" license above, please follow below link for the End User Agreement:

www.tue.nl/taverne

Take down policy

If you believe that this document breaches copyright please contact us at:

openaccess@tue.nl

providing details and we will investigate your claim. 


\title{
STRUCTURAL MODELLING, CONSTRUCTION AND TEST OF THE FIRST 3D-PRINTED GRIDSHELL IN ICE COMPOSITE
}

\author{
Arno PRONK ${ }^{1}$, Qingpeng LI²*, Elke MERGNY³ \\ Department of the Built Environment, Eindhoven University of Technology \\ 1.D.C.Pronk@tue.nl, \\ School of Architecture and Urban Planning, Nanjing University, Nanjing 210093, China \\ $2^{\star}$ hitssrclqp@gmail.com \\ Faculty of Applied Science, University of Liege \\ ${ }^{3}$ elke.mergny@ulg.ac.be
}

\section{Editor's Note:}

DOI:

\section{ABSTRACT}

In the past, record breaking large shell structures with ice composites were successfully realized by spraying cellulose-water mixture on an inflatable mould. This paper presents the application of a new, production technique for ice composites by extrusion instead of spraying. With this additive manufacturing technique, the world's first gridshell in fibre-reinforced ice was designed, constructed, and tested. To increase the stiffness of the gridshell the floorplan of the inflatable mould was designed with an anti-clastic curvature at the supports of the structure. Concerning the pattern of the grid different options were developed and compared and verified in ABAQUS®. The size of the struts were determined by an iterative process. The gridshell was realized in a cold environment by printing multiple layers of cellulose-water mixture on the inflatable mould using piping bags. After the substance has been extruded, the mixture froze at temperatures of minus eight degrees Celsius or lower. The realized structure was tested on-site with a dead load to prove its strength.

Keywords: Gridshell, ice composite, structural modelling, inflatable mould, 3D printing, loading test.

\section{INTRODUCTION}

This research into ice and ice composites is part of a large movement to research new sustainable building materials. Ice and water is available, cheap, and fully cyclic without waste, and has a low $\mathrm{CO}_{2}$ emission. In the past centuries, artists, architects and engineers have explored possibilities to apply ice. Igloos are well-known examples of simple structural objects made by ice blocks. More impressive structures made of ice blocks were made since 1739 (the first ice palace in St. Petersburg, Russia [1]). In 1942, Geofry Pyke learned from a report by Herman Mark and his assistant that ice made from water mixed with wood fibers formed a strong solid mass, which is much stronger than pure water ice [2]. Triggered by this report, Perutz researched the properties of ice composites made of sawdust and ice [3]. Isler experimented with thin shell structures of ice over many years. He made a range of frozen shapes using just water and fabric, including frozen hanging model, tent-like shells, etc. [4]. During the 1980s and 1990s, Kokawa developed a method for spraying 'snice', that a special wet snow that can easily be sprayed on moulds to make igloos with a large span [5]. By combining ice composites with the spraying method developed by Kokawa, an ice research group at the Eindhoven University of Technology (TU/e) led by Pronk proved that through spraying ice composite it also increases its strength and resistance to impact and shock-loading. A relatively small amount of fibers was required to improve the mechanical properties of ice drastically. In a further research study, the wood fibers in the mixture were replaced by cellulose fibers, which have the same impact on the properties of ice [6]. By using fiber-reinforced ice, the largest igloo dome structure with a span of $30 \mathrm{~m}$ was realized in 2014 [7]. In 2016, an attempt was made to construct an ice bridge with a free span of 35 meters [8]. In 2018, the Flamenco tower claimed the position as highest ice tower ever built with a height of $30.5 \mathrm{~m}$ [9]. All three structures were built by students of Eindhoven University of Technology, in cooperation with other schools and universities guided by Pronk, using an inflatable mould as formwork. In addition, Coar realized a number of fabric formed ice shell 
structures by using fiberglass bars and hanging fabrics as a mould for an ice shell in 2011, and in 2015 he produced a fabric formed ice origami structure in cooperation with MIT and VUB [10]. These achievements have shown that engineers and design teams are able to successfully realize icebased (shell) structures with different mixtures and different shapes.

In this paper the focus on spraying ice composites was moved to the new possibilities of 3D printing of ice composites. 3D printing of ice is one of the building methods that can be used to print a mould, 3D habitat, sculpture or temporary foundation of ice in cold environments such as Mars or the poles. In these areas water and ice are one of the few locally available materials. To research the possibility of 3D printing of ice, a gridshell in ice was, designed, engineered, constructed and tested. In this project the following techniques were developed and tested:

- The use of an inflatable mould for a gridshell.

- The structural optimization and behavior of the grid.

- The printing of layers of ice composite on a slope.

- The structural behavior of the gridshell in ice composite.

Three design variants of the gridshell are discussed, shown in Figure 1. From Li's research [11], it is preferred to have inward curved supports in order to increase the stiffness of the shell structure. Also considering the gridshell should have openings, the general shape of the third variant was considered to be both architecturally and structurally pleasing.
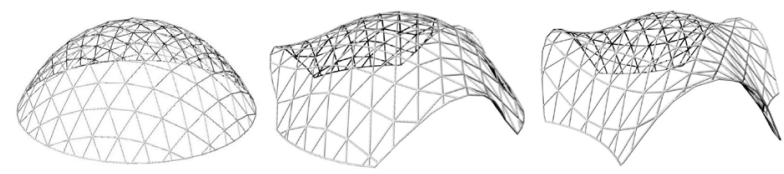

Figure 1: Three design variants of the gridshell.

\section{FORM ACTIVE DESIGN OF THE INFLATABLE MOULD}

In this section, the process of designing the inflatable mould is introduced.

\subsection{Design Considerations}

The gridshell will be 3D printed on an inflatable mould. This way of construction involves some constraints. An inflatable will always form a circular cross-section in at least one direction. This circular form occurs due to the stress leveling of internal and external pressure and the stresses in the membrane. While a gridshell performs mainly on compressive stresses and therefore, the ideal shape of a gridshell will usually approach a catenary line. It is possible to bring an inflatable shape into a catenary line shape rather than a circular shape up to a certain extent. To obtain the desired shape, the constraints that an inflatable mould involves need to be considered during the entire design process.

Another aspect that needs to be considered with respect to the inflatable mould is the practical construction of the gridshell in ice. From practical considerations, it would be favorable to make the inflatable a bit oversized compared to the final gridshell. The size will be corrected by a rope net at the locations where material is required in the gridshell design. Then the shape of the inflatable could be a bit inaccurate without that having severe consequences for the design. This possibility of inaccuracy is desired as the designed inflatable will have a double curved shape. For such shapes, it is hard to exactly determine the cutting patterns which will result in the desired shape. Thus even the inflatable is a bit larger than the actual gridshell, minor inaccuracies in the inflatable shape will not lead to a different final shape of the gridshell.

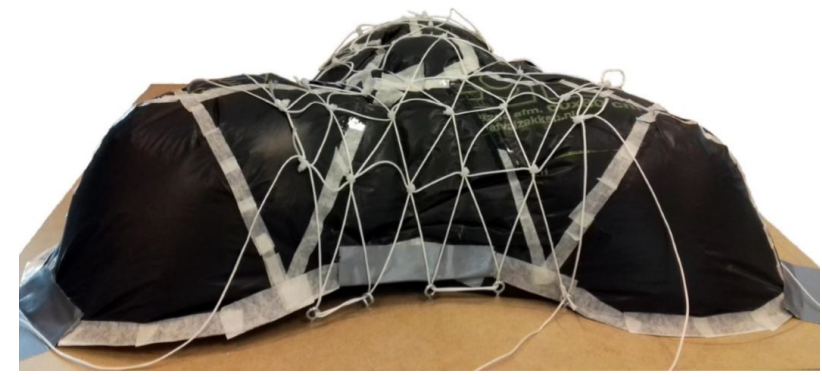

Figure 2: A physical model of inflatable with a rope net.

The final shape of the gridshell is defined by using a rope net attached to the inflatable mould. A rope net can function both to fix the inflatable to the ground and to achieve the form-finding of the inflatable and the grid. Summarized, the ropes will compensate for the over-dimensioning of the inflatable and they will automatically reveal a grid-pattern on the inflatable. Therefore, this rope net can also be used as a guideline for the $3 \mathrm{D}$ printing. The main advantage of this is that it is easy to see where the ice should be printed. Secondly, following the ropes when printing the ice-mixture will result in more constant crosssections of the ice grid compared to printing perpendicular to the ropes. This is because the rope net will lead to depressions along the cables on the 
surface of the inflatable mould. A physical model of this project which can explain above introduction is shown in Figure 2.

\subsection{Design of the Inflatable Mould}

The design variant was modelled in the parametric modeling environment of Rhinoceros [12] with the plugin Grasshopper [13]. As mentioned before, there were some issues with combining the optimal shape of a shell/gridshell with the possibilities that a pneumatic formwork can offer. Then this modelling method should first ensure that a feasible inflatable shape is modelled.

Construction of the model started with the definition of the ground shape of the desired gridshell. The largest diameter of the final gridshell approximately $4.0 \mathrm{~m}$ is selected, and thus the gridshell will have a height of approximately $1.8 \mathrm{~m}$. Then the ground shape of the inflatable was made suitable for these dimensions as well. The inflatable ground shape consists of six arcs of which three are directed inwards and form the supports (the black arcs in Figure 3). The other three arcs (the green ones in Figure 3) are constructed such that their endpoints have the same tangent line (so the same curvature and direction) as the endpoints of the black arcs to which they are connected. This modeling method assures that no kinks occur in the structure at the transition from concave to convex curvature.

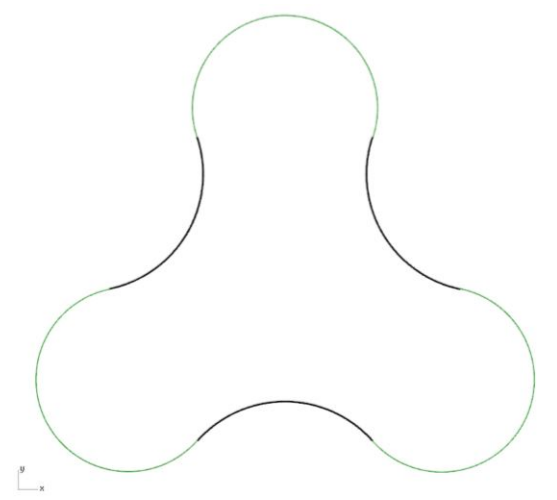

Figure 3: Top view of the six arcs that form the basis of the design of the inflatable

The six arcs were coupled to create one ground shape after which this shape was repeatedly divided into three pieces. These three pieces were revolved around their central axes resulting in a circular form of the created geometries in vertical direction (Figure 4). After this step, a gap remained in the center of the geometry. Infill was given to this gap by means of fitting part of a sphere that has the same curvature and direction at the locations where it intersects with the parts from Figure 4. By joining the four pieces of geometry, the inflatable was finally created with at each location a circular cross-section in at least one direction, shown in Figure 5.

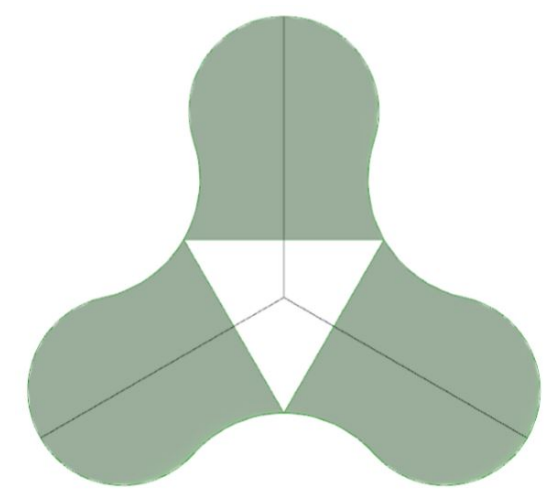

Figure 4: Top view of the revolved surfaces (green) and their axes of revolution (black)

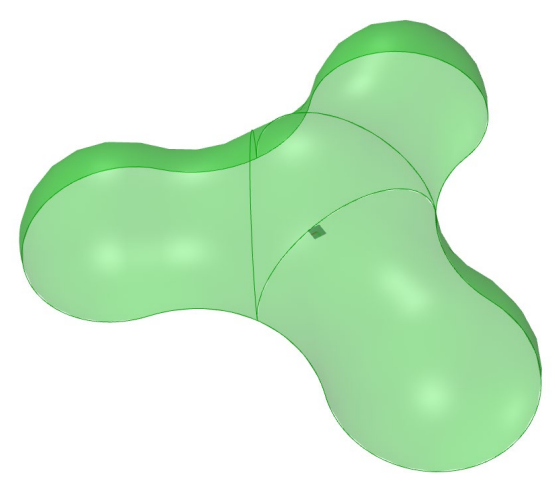

Figure 5: The final 3D inflatable model.

\section{SURFACE ACTIVE DESIGN OF THE ROPE NET AND THE GRIDSHELL}

After the inflatable including its circular shape had been modelled, the grid morphology of the gridshell is designed. Different ways of modelling or distributing the grid are discussed in this section. Four grid options were designed. All the four grid options will be evaluated based on structural, architectural and practical considerations. The final grid that was chosen will then be further optimized with the help of final element method analysis.

\subsection{Introduction}

Design and verification are made using the software ABAQUS ${ }^{\circledR}$ [14]. The mesh consists of 3-node quadratic beams [15]. Connections between nodes are rigid and the supports are free to rotate.

For the execution of the 3D-printed gridshell in ice, a mixture that consisted of 80 grams of cellulose, 1.5 grams of Guar Gum and 1.5 grams of Xanthan Gum 
per liter of water was used. Relevant mechanical data for this composite were derived from experiments that was performed in the Pieter van Musschenbroek laboratory in Eindhoven. The design values for the material properties of the ice composite and of the rope are given in Table 1. The torsion is not verified in this analysis. The ropes have a circular crosssection, with diameter equal to $10 \mathrm{~mm}$. The ice behaves elastically and the geometric non-linear behavior of the rope is taken into account.

Table 1: Material proprieties

\begin{tabular}{|l|l|l|}
\hline & Ice & Rope \\
\hline Density & $900\left[\mathrm{~kg} / \mathrm{m}^{3}\right]$ & $0.9[\mathrm{~kg} / \mathrm{m}]$ \\
\hline Young modulus $[\mathrm{MPa}]$ & 550.00 & 1300.00 \\
\hline Poisson ratio & 0.15 & 0.45 \\
\hline Tensile strength $[\mathrm{MPa}]$ & 0.30 & \\
\hline $\begin{array}{l}\text { Compressive strength } \\
\text { [MPa] }\end{array}$ & -1.00 & \\
\hline
\end{tabular}

The pressure inside the inflatable was assumed to be $200 \mathrm{~Pa}$ and gravity acceleration is considered equal to $9.81 \mathrm{~m} / \mathrm{s}^{2}$.

\subsection{Design of the Rope Net}

Four options were studied for designing the rope net. The first design was obtained by projecting a regular grid on the inflatable shape, which is showed in Figure 6.

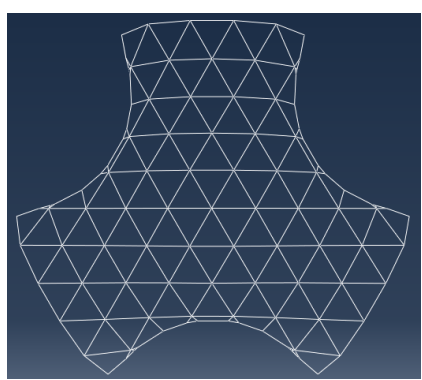

Figure 6: $A B A Q U S \AA$ finite element model of the option 1.

The second option is based on curves generated by the intersection between the inflatable and horizontal planes (see Figure 7).

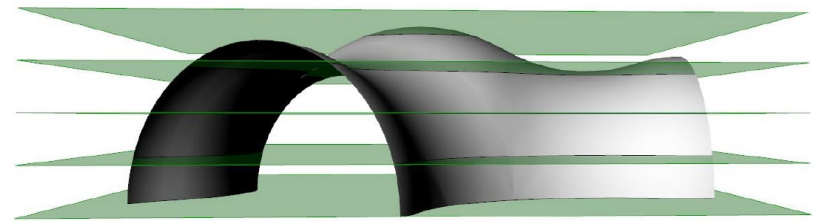

(a) Intersection between the inflatable and horizontal planes.

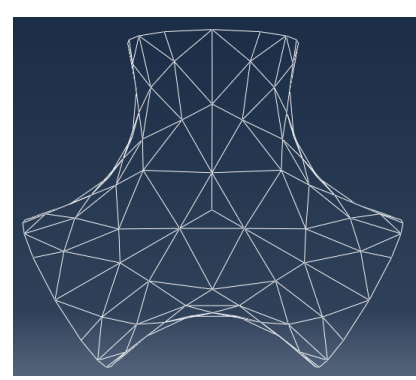

(b) ABAQUS® finite element model of the option 2.

Figure 7: Option 2.

The third option was to build using a central "Y"shape, as shown on Figure 8(a). The forces are transferred through these curves to the ground. The lines were then divided in equal length segments (shown in Figure 8(b)).

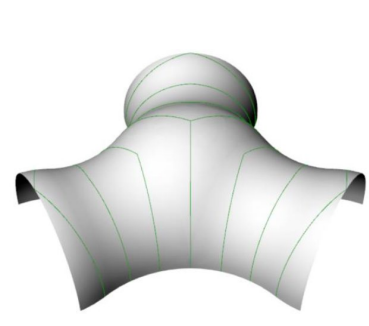

(a) Main lines.

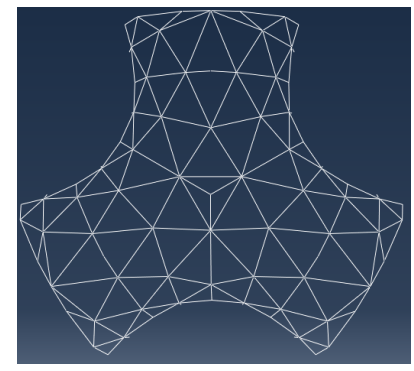

(b) $A B A Q U S \circledR$ finite element model.
Figure 8: Option 3.

The last studied design was based on a quadrilateral grid, shown in Figure 9. It has a basis of rhombuses at its three sides. The number of intersection are thus reduced compared to the grids based on triangular shapes, resulting in a slender and delicate appearance.

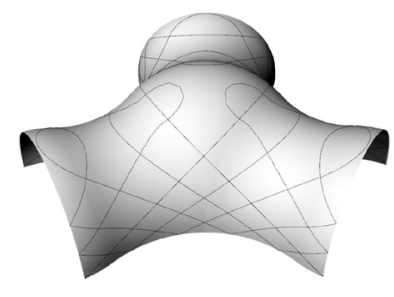

(a) Main lines.

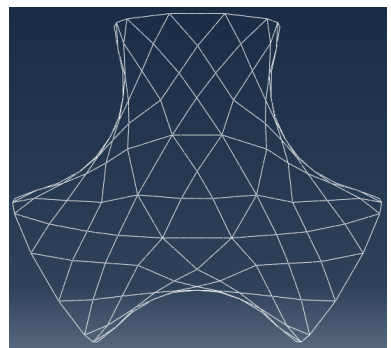

(b) $A B A Q U S \circledR$ finite element model.
Figure 9: Option 4.

A comparative study was carried out subsequently. ABAQUS ${ }^{\circledR}$ simulations were performed for each option, considering 10 circular cross-sections with diameter between 0.05 and $0.15[\mathrm{~m}]$, shown in Figure 10. The lightest structure is the option 4 
(Figure 10(a)) and the option 2 is the heaviest. The first and third designs give the lowest stresses and displacements, as shown in Figures 10(b) and (c). Option 2 can be eliminated: it is heavier than options 1 and 3 and stresses and displacements are also larger. Option 4 is a light quadrilateral grid and is consequently less stiff than the other configurations. Thus, it has the largest stresses and displacements. A large cross-section would be necessary to avoid failure and large deformations.

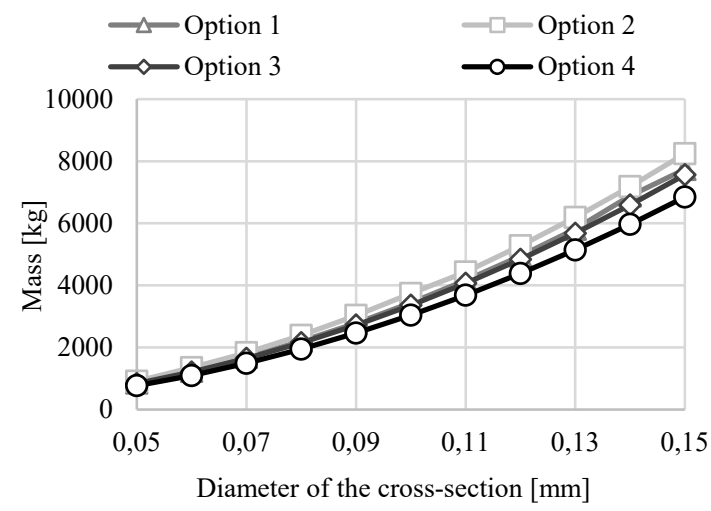

(a) Weight of the configuration

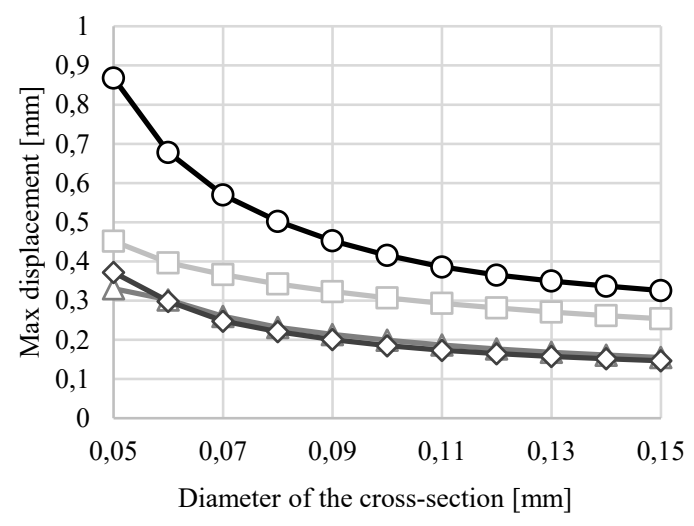

(b) Maximum displacement

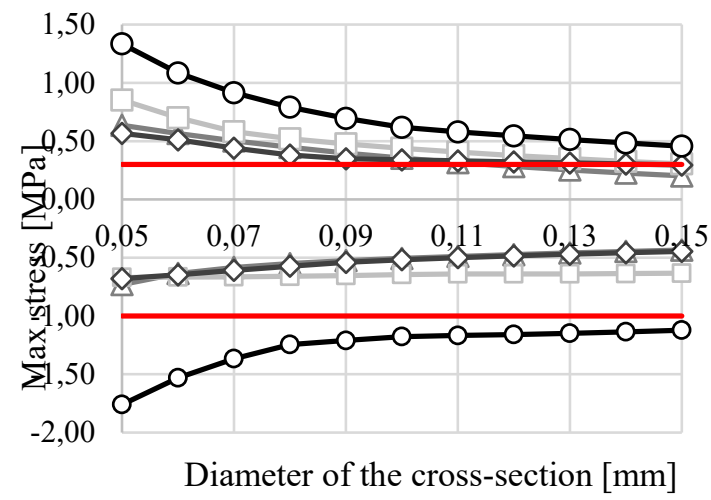

(c) Maximum stresses in tension (positive) and in compression (negative)

Figure 10: Comparison curves.

\subsection{Design of the gridshell}

From an aesthetic point of view, the fourth option was the most satisfying but this design was less stiff compared to the grids based on triangles. The final design is thus based on options 3 and 4 (shown in Figure 12 and 13). Lines that allows the transfer of the forces to the ground were added to the quadrilateral grid and the density of the grid was made higher near the supports because of the high compression forces and bending moment in the more vertically oriented parts.

Figure 11 shows an overview of the stress areas with high tension, compression or bending stresses. The compression forces are the highest and located at the ground level. The diameter of the cross-sections will thus be higher in this area. The final gridshell design and sections were obtained using an iterative process to minimize deformations and compression and tensile stresses, under self-weight. These multiple analyses were performed with ABAQUS ${ }^{\circledR}$. Figure 12 shows the final circular cross-section.

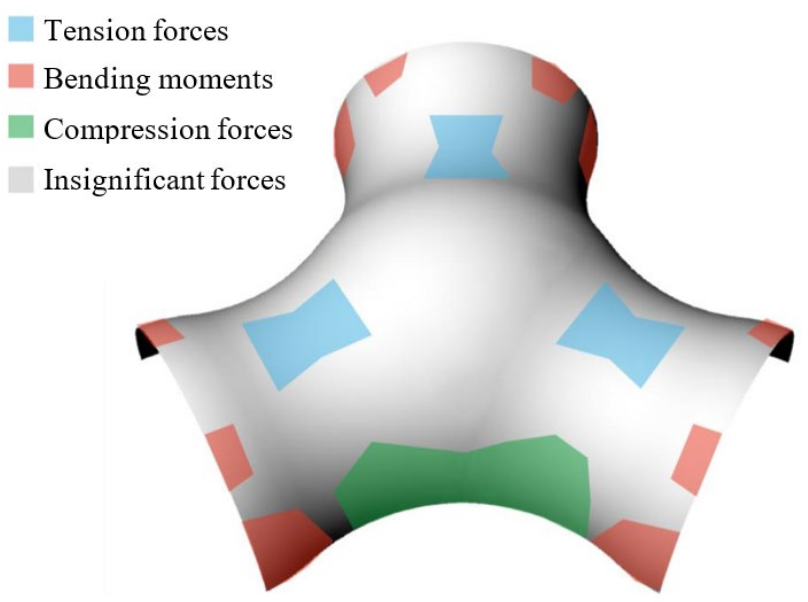

Figure 11: Overview of the critical areas.

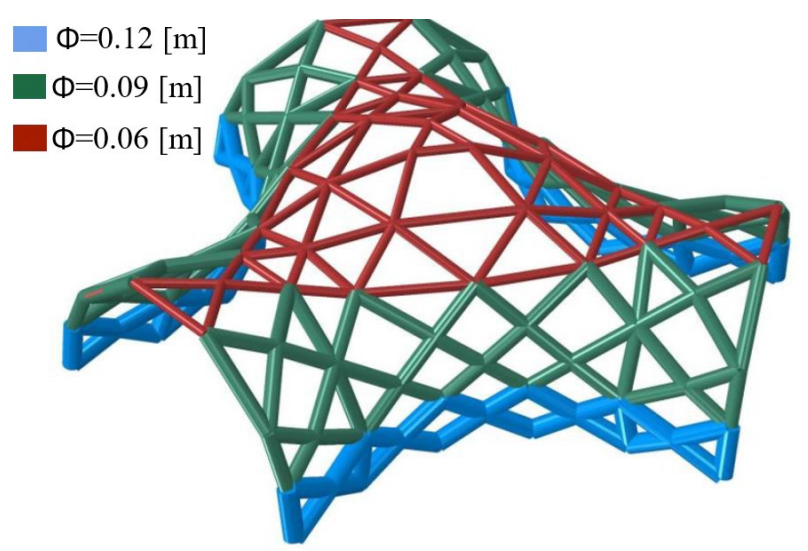

Figure 12: Final cross-sections. 


\section{STRUCTURAL ANALYSIS OF THE GRIDSHELL}

In this section, structural analyses of the final design under its self-weight and during construction were performed, using the software ABAQUS $®$.

\subsection{Structural analysis of the gridshell in ABAQUS® under self-weight}

Figure 13 shows the finite element model of the ice composite gridshell in ABAQUS $\AA$. Table 2 contains the maximum stresses when the structure is subjected to self-weight, and the design values for the maximum compression stress and maximum tensile stress.

The stresses are taken from the perimeter of the circular cross section (relative radius is equal to 1 ) and calculated for the four main angles $\left(0^{\circ}\right.$ is the bottom location section point and $180^{\circ}$ is the top). The maximum compression occurs at the top location section point (angle $=180^{\circ}$, Figure 14) and the maximum tensile stress was found at the bottom of the cross section (angle $=0^{\circ}$, Figure 15).

These stresses are within the acceptable limits. The largest vertical displacement is equal to $0.47 \mathrm{~mm}$ and occurs at the openings of the gridshell (Figure 16), where the stresses are also the highest.
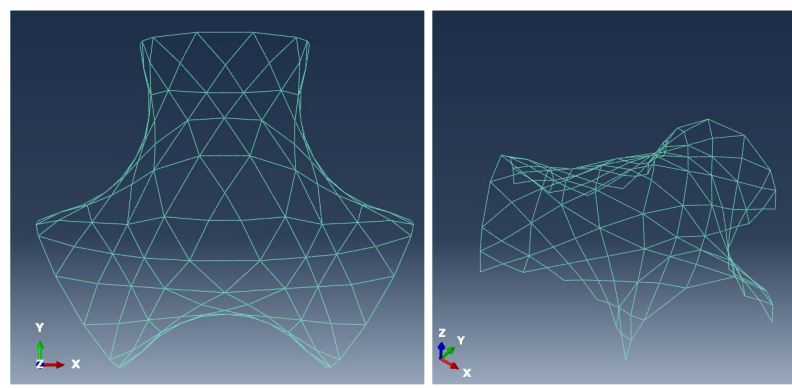

Figure 13: ABAQUS ${ }^{\circ}$ finite element model of the gridshell.

Table 2: Maximum stresses under self-weight.

\begin{tabular}{|l|l|l|l|}
\hline & $\begin{array}{l}\text { Angle } \\
{\left[{ }^{\circ}\right]}\end{array}$ & $\begin{array}{l}\text { Max tensile } \\
\text { stress }[\mathrm{MPa}]\end{array}$ & $\begin{array}{l}\text { Max compr. } \\
\text { stress }[\mathrm{MPa}]\end{array}$ \\
\hline \multirow{4}{*}{$\begin{array}{l}\text { Self- } \\
\text { weight }\end{array}$} & -90 & 0.053 & -0.066 \\
\cline { 2 - 4 } & 0 & 0.061 & -0.102 \\
\cline { 2 - 4 } & 90 & 0.045 & -0.068 \\
\cline { 2 - 4 } & 180 & 0.085 & -0.074 \\
\hline $\begin{array}{l}\text { Design } \\
\text { value }\end{array}$ & $/$ & 0.30 & -1.0 \\
\hline
\end{tabular}

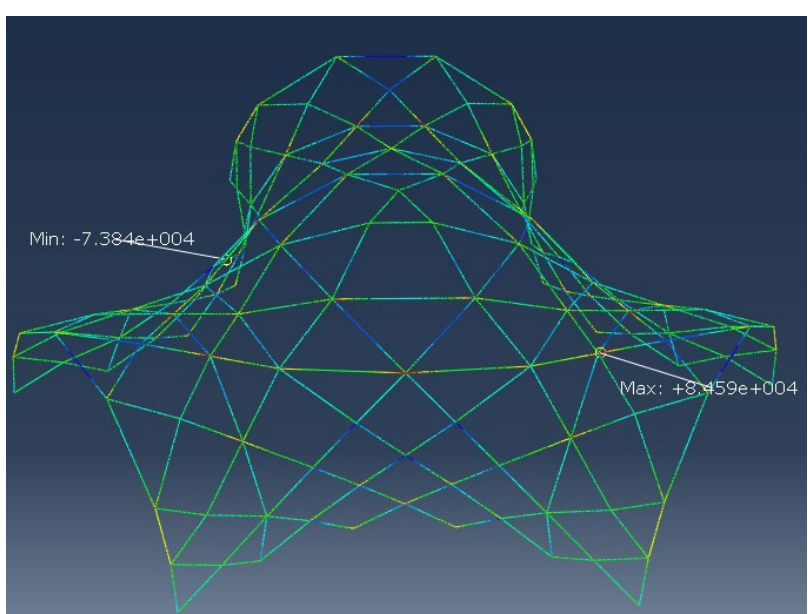

Figure 14: Axial stresses [Pa] (angle $=180^{\circ}$, top side of the elements).

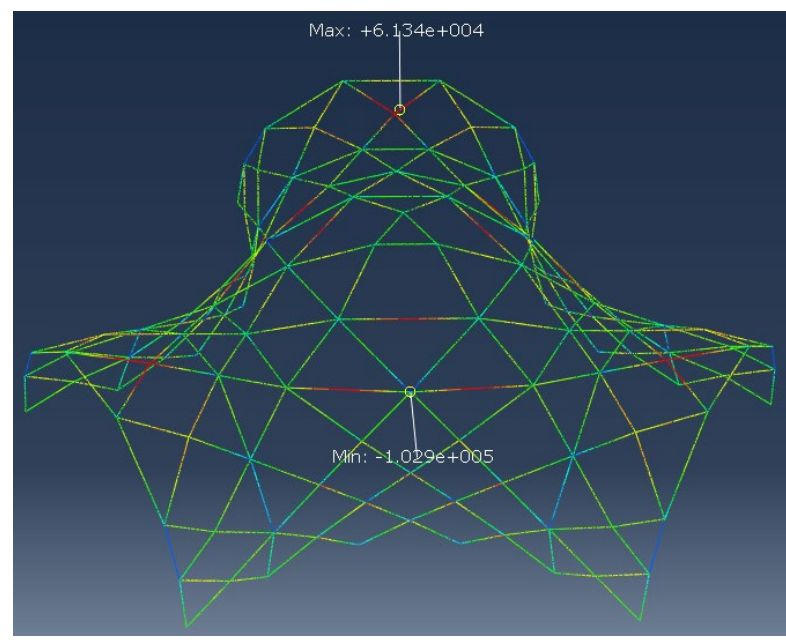

Figure 15: Axial stresses [Pa] (angle $=0^{\circ}$, bottom side of the elements).

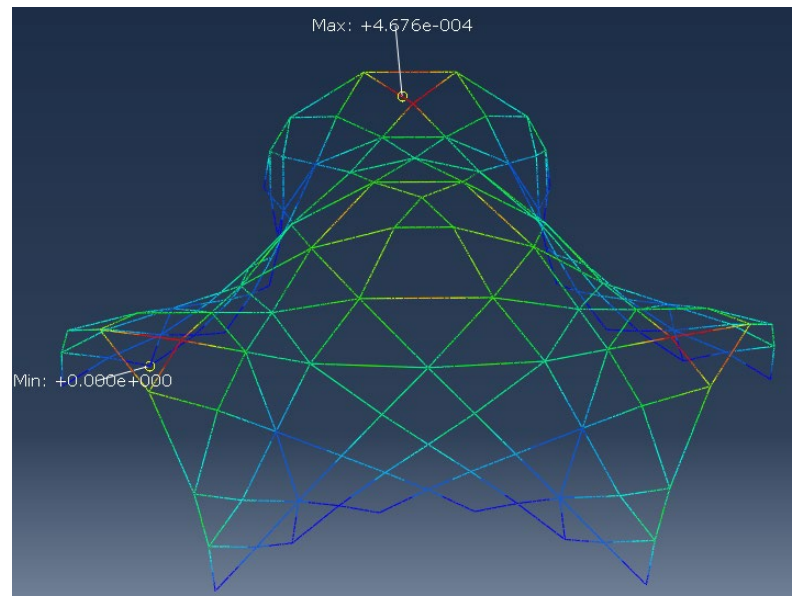

Figure 16: Vertical displacement $[\mathrm{m}]$.

4.2 Structural analysis of the gridshell in ABAQUS® during construction

Detailed structural analysis of the final design is 
conducted in this section to guide the construction process.

\section{Phase 1}

In this step, a part of the lower gridshell is modelled (Figure 17). The cross-section of the bars were reduced to $6 \mathrm{~cm}$ for the bottom elements and $3 \mathrm{~cm}$ for the part above, since the final thickness has not yet been reached during the construction phase.

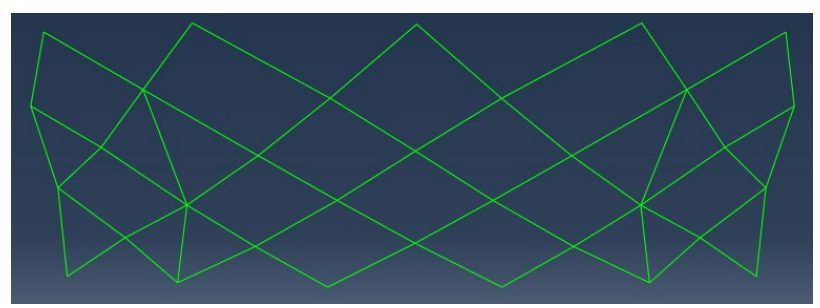

Figure 17: ABAQUS $®$ finite element model of phase 1 .

Table 3 shows that maximum stresses are within the acceptable limits.

Table 3: Maximum stresses of Phase 1.

\begin{tabular}{|l|l|l|l|}
\hline & $\begin{array}{l}\text { Angle } \\
{\left[{ }^{\circ}\right]}\end{array}$ & $\begin{array}{l}\text { Max tensile } \\
\text { stress [MPa] }\end{array}$ & $\begin{array}{l}\text { Max compr. } \\
\text { stress [MPa] }\end{array}$ \\
\hline \multirow{4}{*}{ Phase 1 } & -90 & 0.251 & -0.123 \\
\cline { 2 - 4 } & 0 & 0.284 & -0.176 \\
\cline { 2 - 4 } & 90 & 0.174 & -0.244 \\
\cline { 2 - 4 } & 180 & 0.167 & -0.285 \\
\hline $\begin{array}{l}\text { Design } \\
\text { value }\end{array}$ & $/$ & 0.30 & -1.00 \\
\hline
\end{tabular}

\section{Phase 2}

Considering a second construction stage, a larger part of the gridshell was modeled also with reduced cross-sections.

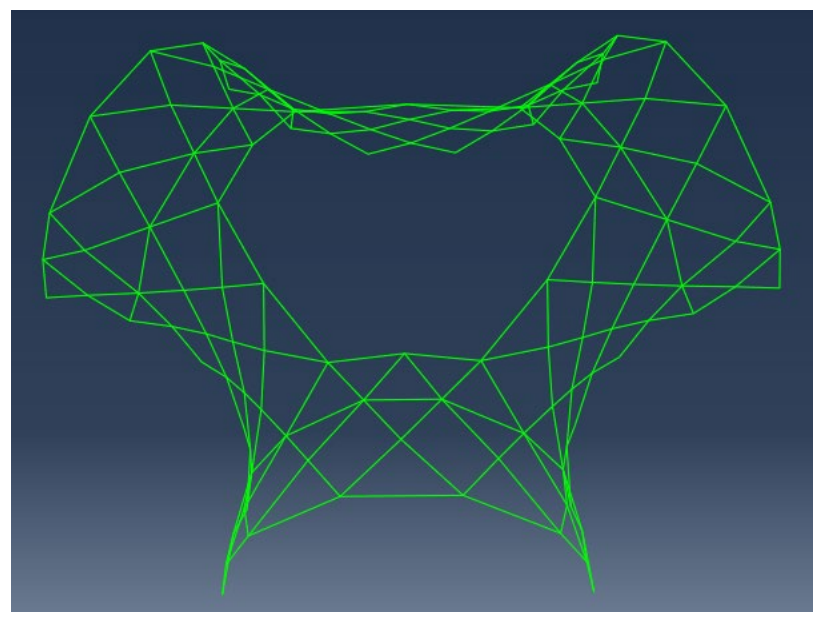

Figure 18: ABAQUS $®$ finite element model of phase 2.
Tensile stresses and compressive stresses are below the design limits for compression and tension strength (Table 4).

Table 4: Maximum stresses of phase 2.

\begin{tabular}{|l|l|l|l|}
\hline & $\begin{array}{l}\text { Angle } \\
{\left[{ }^{\circ}\right]}\end{array}$ & $\begin{array}{l}\text { Max tensile } \\
\text { stress [MPa] }\end{array}$ & $\begin{array}{l}\text { Max compr. } \\
\text { stress [MPa] }\end{array}$ \\
\hline \multirow{4}{*}{ Phase 2 } & -90 & 0.087 & -0.095 \\
\cline { 2 - 4 } & 0 & 0.098 & -0.201 \\
\cline { 2 - 4 } & 90 & 0.091 & -0.064 \\
\cline { 2 - 4 } & 180 & 0.152 & -0.151 \\
\hline $\begin{array}{l}\text { Design } \\
\text { value }\end{array}$ & $/$ & 0.30 & -1.00 \\
\hline
\end{tabular}

\section{CONSTRUCTION AND LOADING TEST OF THE GRIDSHELL}

In this section, the $3 \mathrm{D}$ printing process and the loading test of the gridshell in ice composite are introduced in detail.

\subsection{Construction}

Several printing methods were tested to find the best printing technique.

- Manual extrusion with piping bags.

- Extrusion with a barrel with overpressure.

- Extrusion with a worm pump.

The first method turned out to be the most simple and reliable. In future projects, the focus will be on the automatization and improvement of the printing process.

With regular devices, a cellulose/water factor up to $5 \%$ could be handled. To extrude a 'pasta' with a viscosity of $250,000 \mathrm{mPa} \cdot \mathrm{s}$, we needed to increase the cellulose/water factor above $5 \%$. Therefore we designed and tested several nozzles that were able to extrude water in the nozzle just before the extrusion of the material. Unfortunately all experiments failed because it is impossible to compress a watercellulose mixture without the forming of clots that would lead to an unreliable process. Therefore we have added xanthan gum and guar gum to bind the water and to lubricate the "pasta". The extrusion of water was not necessary anymore and the result was a more reliable process [16].

To ensure the printing process a test was done in a cooling cell in Venlo (the Netherlands). From the experiences in this cooling cell, it was concluded that the rope net holding the inflatable mould was a crucial part to print the ice on nearly vertical surface. 
Furthermore, it turned out that the printing process was more efficient when the water-cellulose mixture was printed close to its freezing point. In this way the printed material would cure sooner. The rope net was used as guideline for the printing process and for holding and shaping the inflatable formwork. It was knotted according to the grid geometry that was extracted from the digital model. The inflatable formwork was $10 \%$ oversized and constructed by the welding of flat cutting patterns of a PVC coated membrane with polyester fibers.

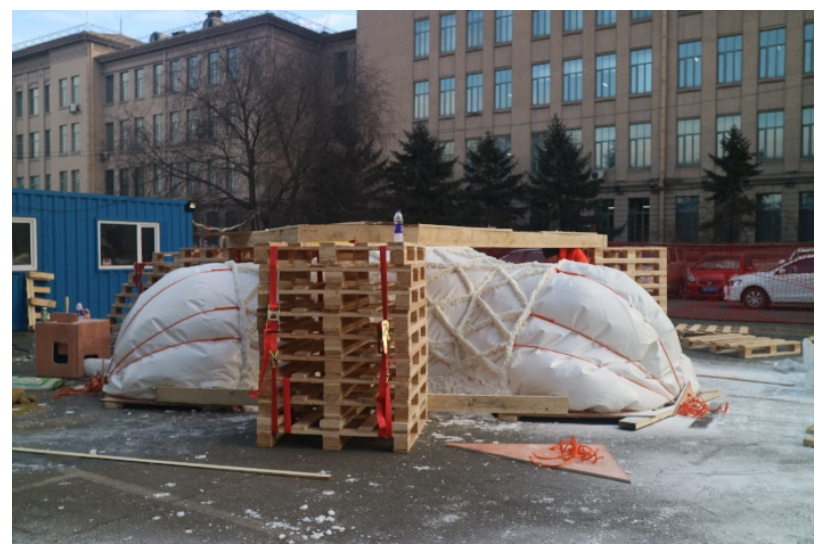

Figure 19: Scaffolding and inflatable mould.

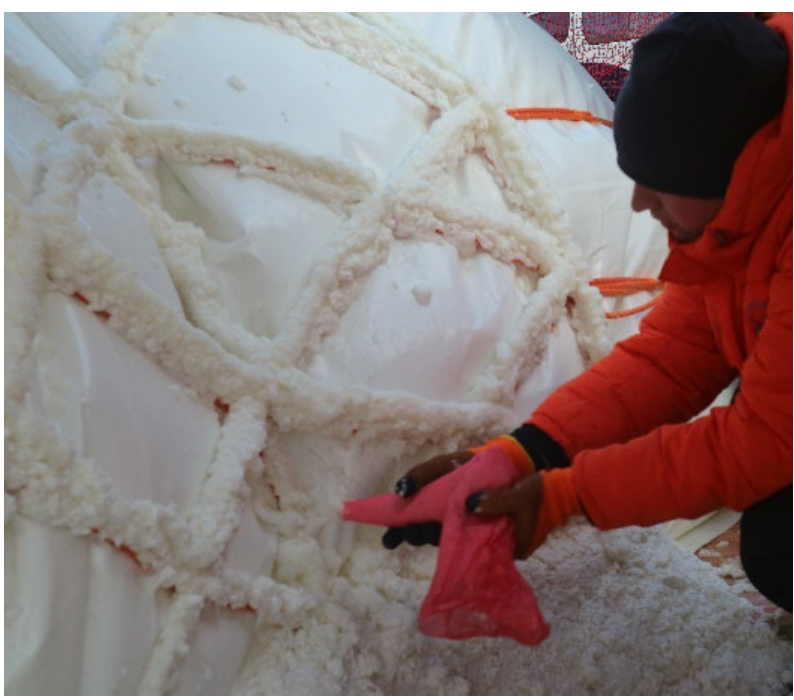

Figure 20: Manual extrusion.

The final gridshell was built in Harbin, China. To reach the top of the structure, scaffolding was required (Figure 19). The curing of the ice composite takes about one hour. To speed up the overall building time the construction of the gridshell was done in a 24/7 continuous process, starting from the foundation going upwards to the top (Figure 20). Figure 21 shows the final gridshell after construction. By the time that all gridlines had the required structural thickness, LED-lights were attached to the gridshell structure (Figure 22) and the inflatable support and scaffolding were removed. Finally, the grid lines and the foundation plate were smoothed by applying the printing techniques.

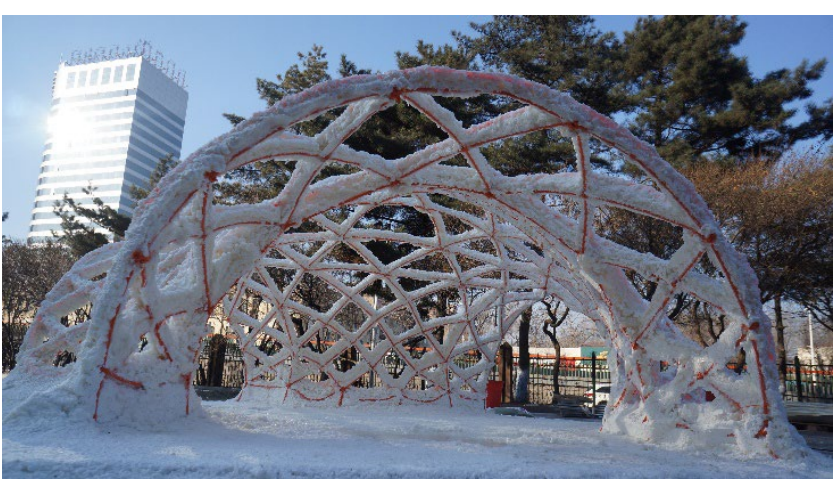

Figure 21: The final gridshell.

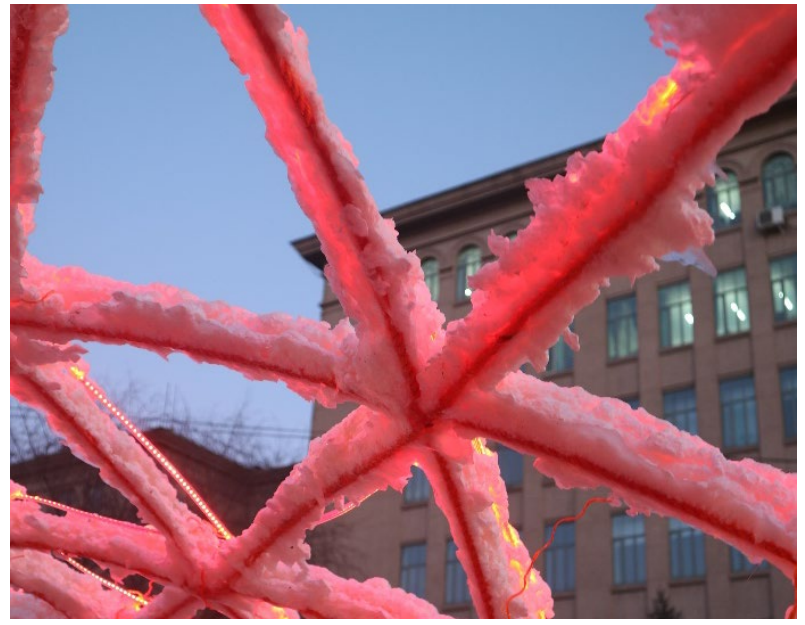

Figure 22: Grid with led light.

\subsection{FEM Simulation of the Loading Test}

Numerical calculations were performed to find the theoretical failure load of the final gridshell subjected to self-weight. The middle part of the structure was loaded as shown on Figure 23, and 21 points loads were applied. Characteristic strength of the ice was taken as the limiting stress.

Failure seems to occur when the point loads reach 2.9 [kN], shown in Figure 24, which corresponds to a total weight of approximately $6100 \mathrm{~kg}$. At this value, the maximum theoretical compression strength of $4.6 \mathrm{MPa}$ is just exceeded.

\subsection{On-site Loading Test}

The calculated failure load was $6000 \mathrm{~kg}$. On 6 January of 2019, the structure was tested at a temperature of -10 Celsius. First $1000 \mathrm{~kg}$ of sand bags were placed on the gridshell by hand. Later two containers were placed on top of the sandbags with a 
crane (Figure 25). The total load on top of the shell was approximately $2500-3000 \mathrm{~kg}$. Although the conditions for testing in practice were limited and not very scientific it proved that the structure, as predicted, was strong enough.

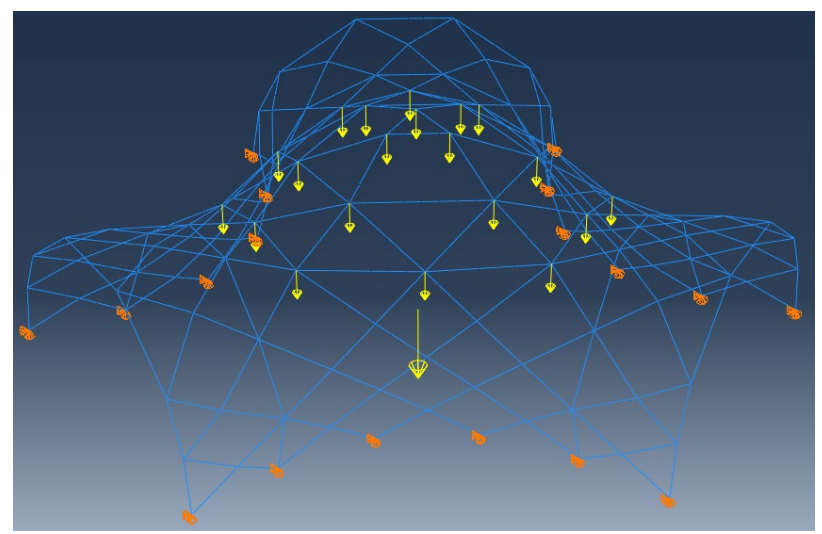

Figure 23: $A B A Q U S \AA$ finite element model of the loading test.

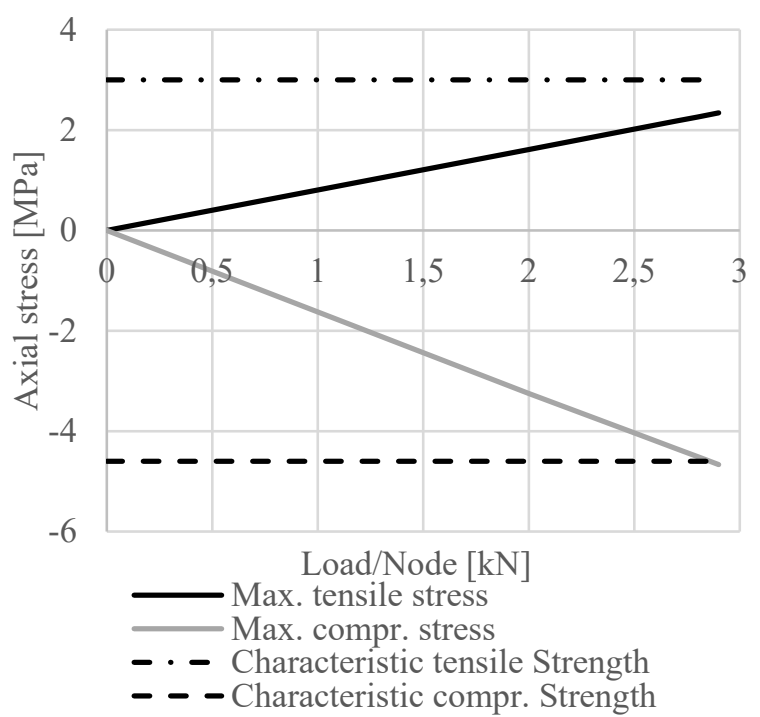

Figure 24: Loading test.

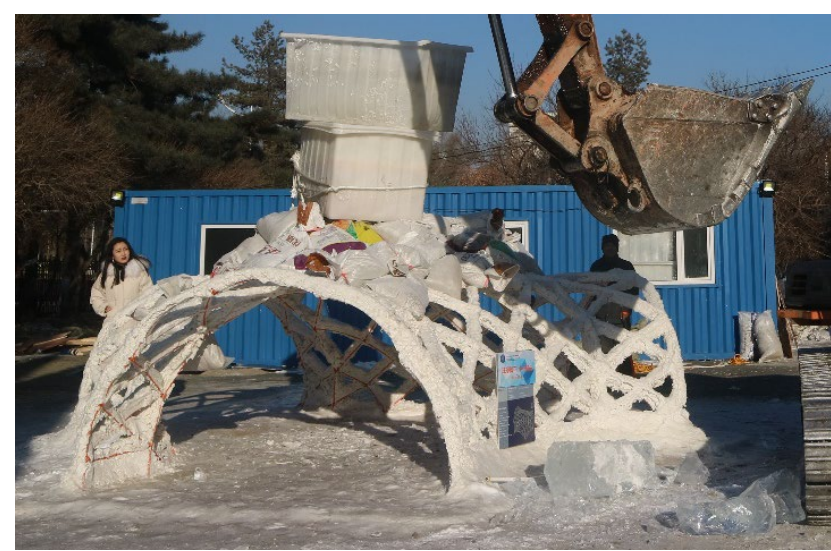

Figure 25: Applied load.

\section{CONCLUSIONS AND PROSPECTS}

This project is the first application of fiber reinforced ice by extrusion. It was also the first time a flexible, inflatable mould was combined with the extrusion of a water-cellulose mixture to realize a gridshell in ice. The construction method was easy and worked very well. The structure and material proved to be strong and ductile. The 3D printing with fiber reinforced ice can be applied for: larger structures, ice festivals, polar missions, sculptures, foundations, castings and Mars missions. The next step will be to automate and improve this method for commercial application.

\section{ACKNOWLEDGMENTS}

The authors thank all students who joined this project and relevant colleagues for their support and contribution. Special thanks are given to Prof. Peng Luo from Harbin Institute of Technology and the university who organized the International Ice and Snow Construction Festival.

\section{REFERENCES}

[1] Herzberg J. The Domestication of Ice and Cold: The Ice Palace in Saint Petersburg 1740. RCC Perspectives, No. 2, On Water: Perceptions, Politics, Perils, 2012, 53-62.

[2] Pykrete.

$<$ https://en.wikipedia.org/wiki/Pykrete> (accessed 2019).

[3] Perutz MF. A description of the iceberg aircraft carrier and the bearing of the mechanical properties of frozen wood pulp upon some problems of glacier flow. Cambridge: Meeting of the Society; 1946.

[4] Chilton J. Form-finding and fabric forming in the work of Heinz Isler. International Society of Fabric Formwork; 2012: 84-91.

[5] Kokawa T. Building Techniques for Ice Shell as Temporary Structure. Proceedings of the IASS-APCS 2012 Symposium; 2012, Seoul, Korea.

[6] Vasiliev N.K., Pronk A.D.C., Shatalina I.N., Janssen F.H.M.E., Houben R.W.G. A Review on the development of reinforced ice for use as a building material in cold regions. Cold Regions Science and Technology, 2015, 115, 56-63. 
[7] Pronk ADC, Borgart A, Hijl JM, Pluijmen RMF. The calculation and construction of a 30 meter span ice dome. Proceedings of the IASS-SLTE 2014 symposium "shells, membranes and spatial structures: footprints", Brasilia, Brazil. 2014.

[8] Pronk ADC, Arntz MHFP, Hermens L. Da Vinci's Bridge in ice and other ice structures with an Inflatable mould. Proceedings of the IASS Annual Symposium 2016. 26-30 September 2016. (Tokyo, Japan).

[9] Pronk A.D.C., Wu Y., Luo P., Li Q., Liu X., Brands J., Blok R., Dong Y. Design and construct of the 30.5 meter Flamenco Ice Tower. Proceedings of the IASS Annual Symposium 2018, 16-20 ${ }^{\text {th }}$ July, 2018, MIT, Boston, USA.

[10] Coar L, Mueller C, Laet de L, Hare J, Wiese K, Oberlin S., Fabrigami: Design and fabrication of an origami-inspired ice and fabric shell, in Proceedings of the International Society of Shell and Space structures, Tokyo, Japan, 26-30 September 2016.

[11] Q. Li. Form Follows Force: A theoretical framework for Structural Morphology and Form-Finding research on shell structures. $\mathrm{Ph}$.D. dissertation. Faculty of Architecture and the Built Environment, Delft University of Technology, Delft, The Netherlands, 2018.

[12] Robert McNeel \& Associates, Rhinocerous, (n.d.). 〈www.rhno3d.com〉.

[13] Robert McNeel \& Associates, grasshopper, (n.d.). 〈http://www.grasshopper3d.com〉.

[14] ABAQUS Analysis user's manual 6.10-EF, Dassault Systems Simulia Corp.,Providence, RI, USA; 2010.

[15] Timoshenko, S. P. On the correction factor for shear of the differential equation for transverse vibrations of bars of uniform crosssection, Philosophical Magazine, 1921: 744.

[16] Pronk A., Moonen Y., Clouds A.O., Luo P., $\mathrm{Wu}$ Y. 3D printing of ice. Proceedings of the IASS 2017 Annual Symposium; 2017, Hamburg, German. 